\title{
New treatment option for an incomplete vertical root fracture-a preliminary case report
}

\author{
Paul Henryk Hadrossek and Till Dammaschke
}

\begin{abstract}
Instead of extraction this case report presents an alternative treatment option for a maxillary incisor with a vertical root fracture (VRF) causing pain in a 78-year-old patient. After retreatment of the existing root canal filling the tooth was stabilized with a dentine adhesive and a composite restoration. Then the tooth was extracted, the VRF gap enlarged with a small diamond bur and the existing retrograde root canal filling removed. The enlarged fracture line and the retrograde preparation were filled with a calcium-silicate-cement (Biodentine). Afterwards the tooth was replanted and a titanium trauma splint was applied for 12d. A 24 months clinical and radiological follow-up showed an asymptomatic tooth, reduction of the periodontal probing depths from $7 \mathrm{~mm}$ prior to treatment to $3 \mathrm{~mm}$ and gingival reattachment in the area of the fracture with no sign of ankylosis. Hence, the treatment of VRF with Biodentine seems to be a possible and promising option.
\end{abstract}

Keywords: Biodentine, Calcium silicate cement, MTA, Treatment, Vertical root fracture

\section{Background}

Vertical root fractures (VRF) are fractures of enamel and dentine along the long axis of the tooth towards the apex $[1,2]$. Besides trauma, a VRF may be caused due to weakening of the dental hard tissue during root canal treatment or restoration, placement of posts and pins, parafunctional habits, heavy stressful chewing and occlusal overload [1-4]. Unfortunately, VRF are serious complications with poor prognosis. Hence, in case of a confirmed diagnosis, therapy of VRF is extraction [1-5]. Main factors which lead to extraction of a fractured tooth are bacterial infiltration causing subsequent inflammation in the fracture area, as well as resorption of nearby alveolar bone induced by defensive cells [6]. Nevertheless, in the past, a variety of approaches have been made to treat VRF, e.g. with cyanoacrylates [7], glass ionomer cement in combination with guided tissue regeneration [8], adhesive composite resins [9-16] and Mineral Trioxide Aggregate (MTA) [4,17-19].

But so far none of these treatment options provided ideal long term results [13]. Thus, these treatment options are more or less of temporary nature as long-term success rates are considerably low [20,21]. Even with MTA the clinical results were disappointing and the

\footnotetext{
*Correspondence: tillda@uni-muenster.de

Department of Operative Dentistry, Albert-Schweitzer-Campus 1, Building W 30, Waldeyerstr. 30, 48149 Münster, Germany
}

attempt to preserve teeth with VRF by using MTA was rejected [4]. Hence, until today, no valid treatment option to preserve teeth with VRF can be recommended. Nevertheless, in this case report for the first time a new treatment option for a maxillary incisor with a VRF is presented. By using a new calcium silicate cement (Biodentine) this fractured tooth could be kept in situ for an observation period of two years - free of any complains until now.

\section{Case presentation}

A 78-year-old patient was referred to the Department of Operative Dentistry because her right central incisor (tooth 11) caused pain for the last 2 years after traumatic injury. Because of the continuous discomfort the tooth had already undergone an endodontic treatment including an apicoectomy after the trauma. On clinical examination the tooth showed a dark coloured fracture line on the labial surface (Figure 1). Furthermore, it showed positive rebound tenderness. The periodontal probing depth adjacent to the fracture line was $7 \mathrm{~mm}$ while the other probing depths showed a non-pathologic value of 2 - $3 \mathrm{~mm}$ (Figure 1).

Actually extraction was the only treatment option for this vertically root fractured tooth followed by an implant, a bridge or a dental prosthesis. None of these treatment 


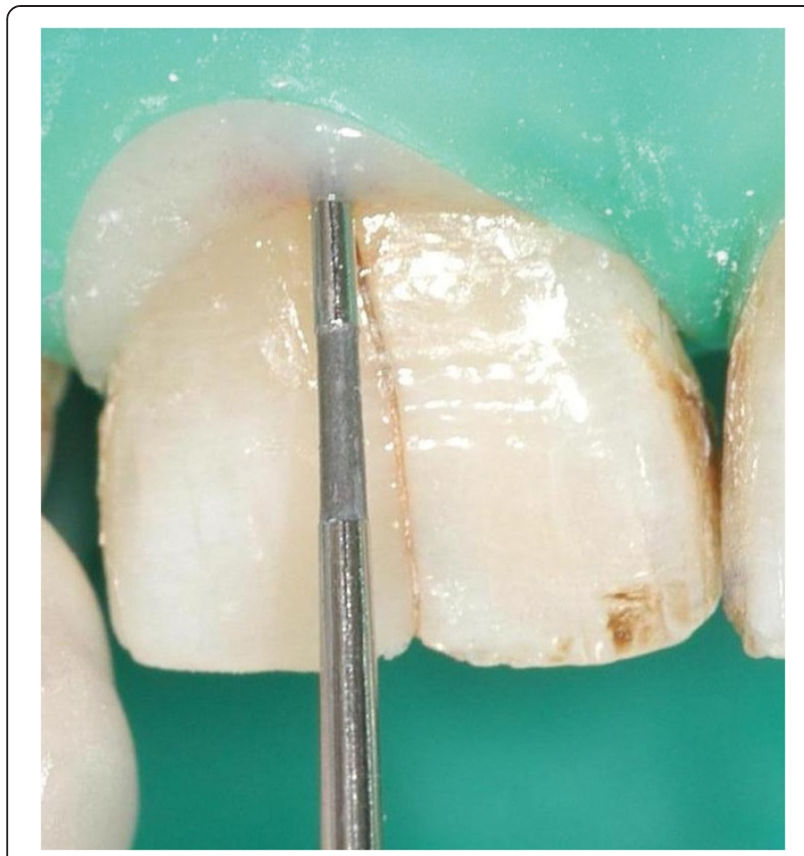

Figure 1 Fracture line on the labial surface of tooth 11 and periodontal probing depth of $7 \mathrm{~mm}$ in the area of the VRF.

options found acceptance by the patient (because of financial or comfort issues). So an alternative and new idea of treating the VRF was discussed, which the patient endorsed.

Under rubber dam isolation the coronal fracture line was enlarged with a small diamond bur. Additionally, $2 / 3$ of the existing root canal filling was removed. The tooth was then stabilized coronally and intracanallary with a dentine adhesive (OptiBond All-In-One; Kerr, Orange, USA) and a composite restoration (Grandio/Grandio Flow; VOCO, Cuxhaven, Germany) (Figure 2). After removing the rubber dam and producing a silicon key (Figure 2), a titanium trauma splint (TTS; Medartis, Basel, Switzerland) was adapted and the area was anaesthetized with Ultracain D-

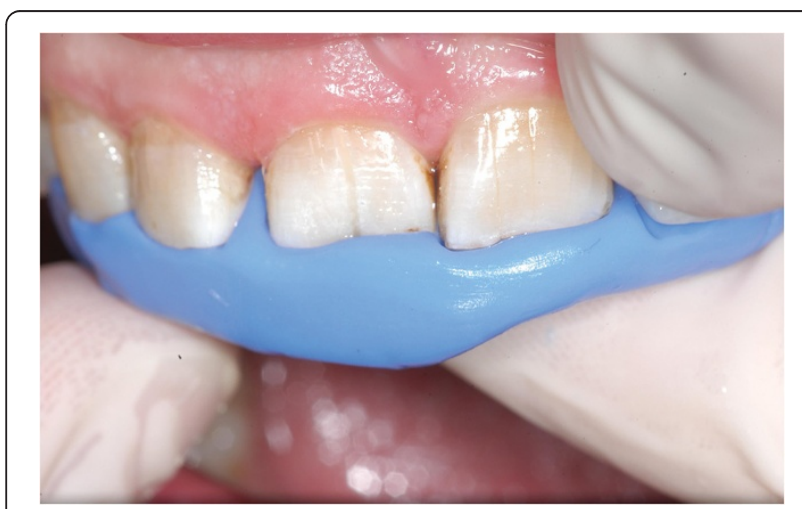

Figure 2 Restored coronal fracture line and silicone key prior to intentional extraction.
S (Sanofi Aventis, Frankfurt, Germany). Tooth 11 was extracted very carefully to protect the surrounding hard and soft tissues and stored in and cleaned with the solution of a Dentosafe tooth rescue box (Medice Pharma, Iserlohn, Germany). While the palatinal surface of the root was unimpaired, the labial surface showed a vertical fracture line (Figure 3). It was enlarged with a small diamond bur and the existing retrograde root canal filling was removed. The enlarged fracture line and the retrograde preparation were filled with Biodentine (Septodont, Saint Maur, France) (Figure 4). While waiting for the Biodentine to set initially, the remaining root surface was constantly rewetted with the Dentosafe solution. Afterwards the tooth was replanted and the titanium trauma splint was applied for $12 \mathrm{~d}$ (Figure 5). The control radiograph showed a successfully replanted tooth 11 (Figure 6). After 3 months a clinical and radiological follow-up already presented an asymptomatic tooth, reduced periodontal probing depths from $7 \mathrm{~mm}$ prior to treatment to $3 \mathrm{~mm}$ and gingival reattachment in the area of the fracture (Figure 7). These findings were identically in the follow-ups after 6,12 and 24 months. The percussion test sounded normal and there was no sign of ankylosis

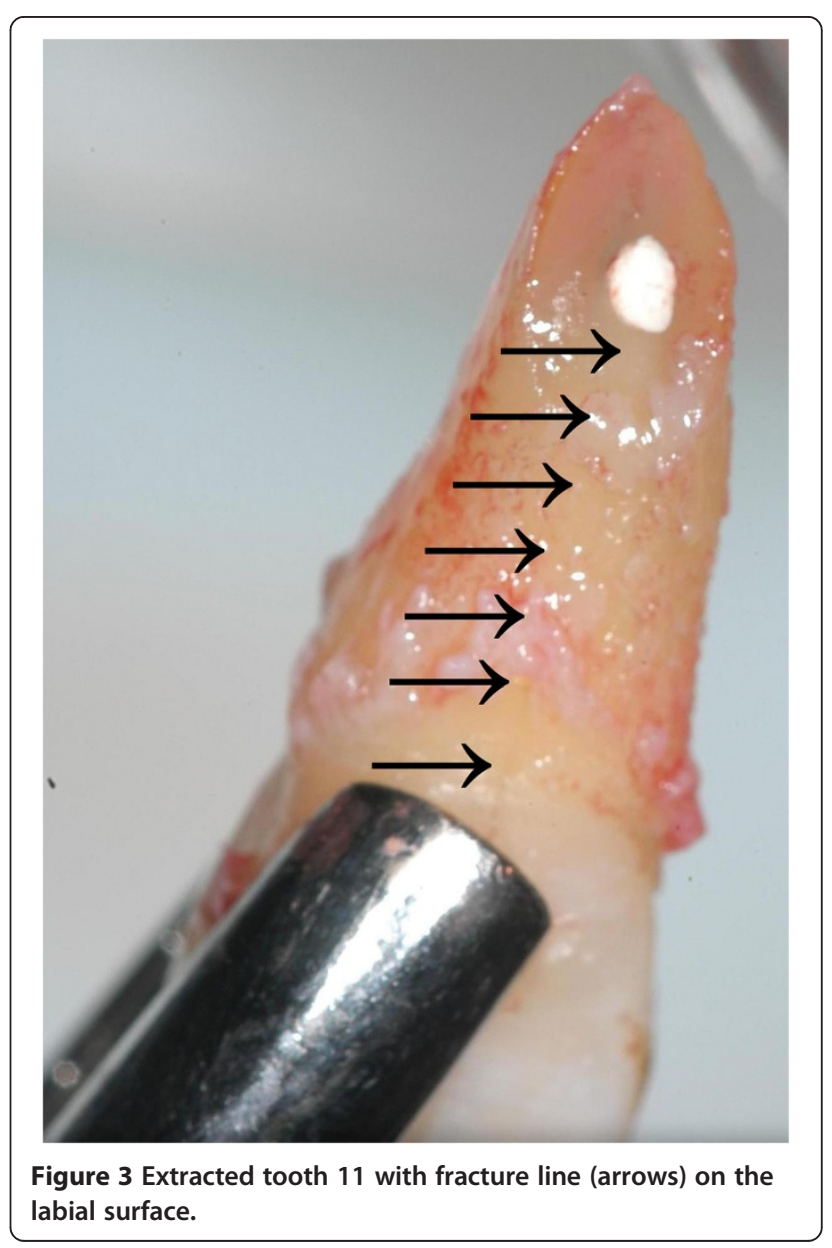




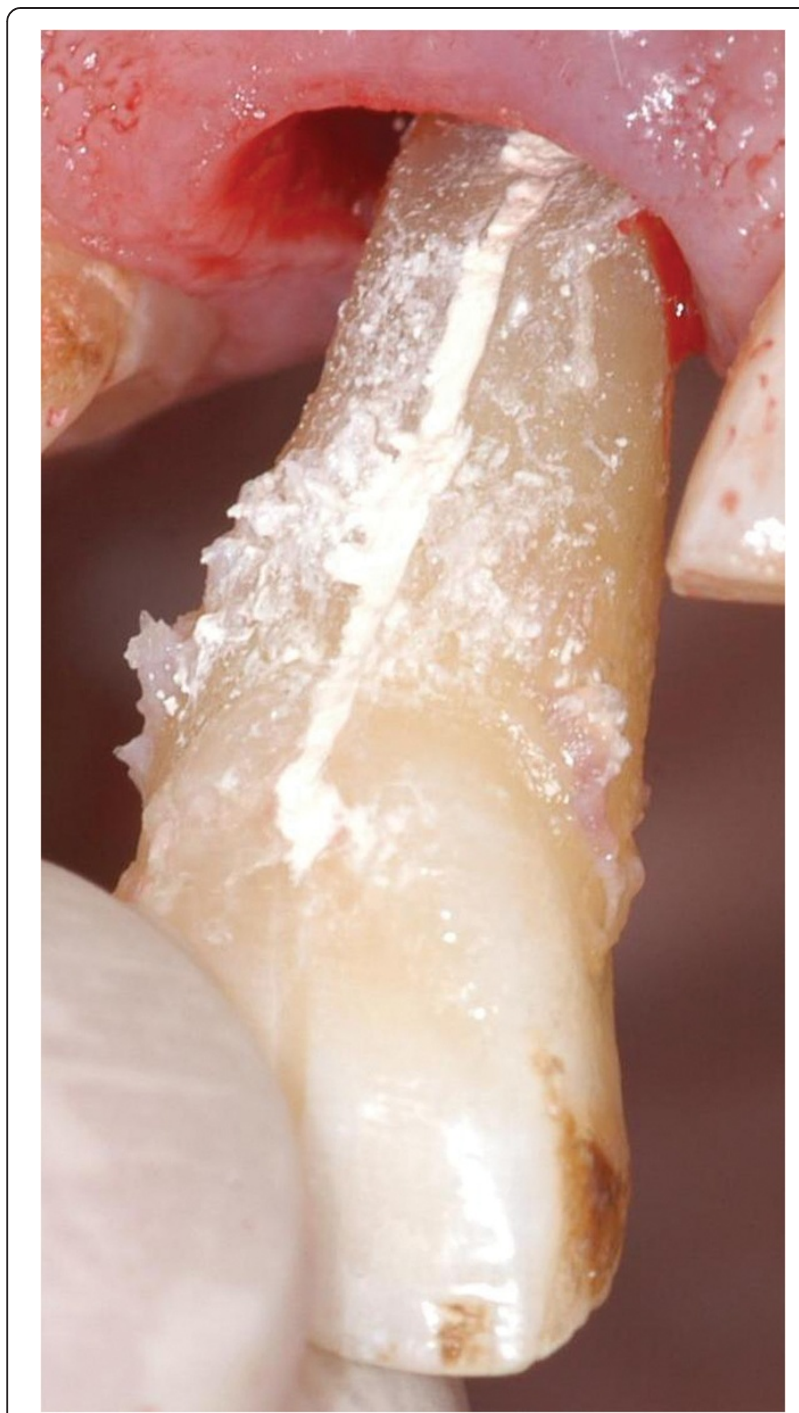

Figure 4 Enlarged fracture line filled with Biodentine (Septodont, St. Maur, France) prior to replantation.

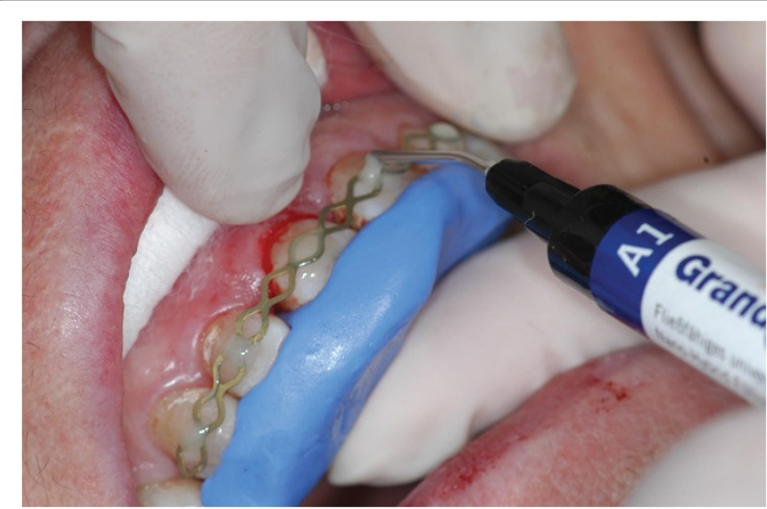

Figure 5 Replanted tooth 11 with silicone key for correct reposition and application of the titan trauma splint (TTS; Medartis, Basel, Switzerland).

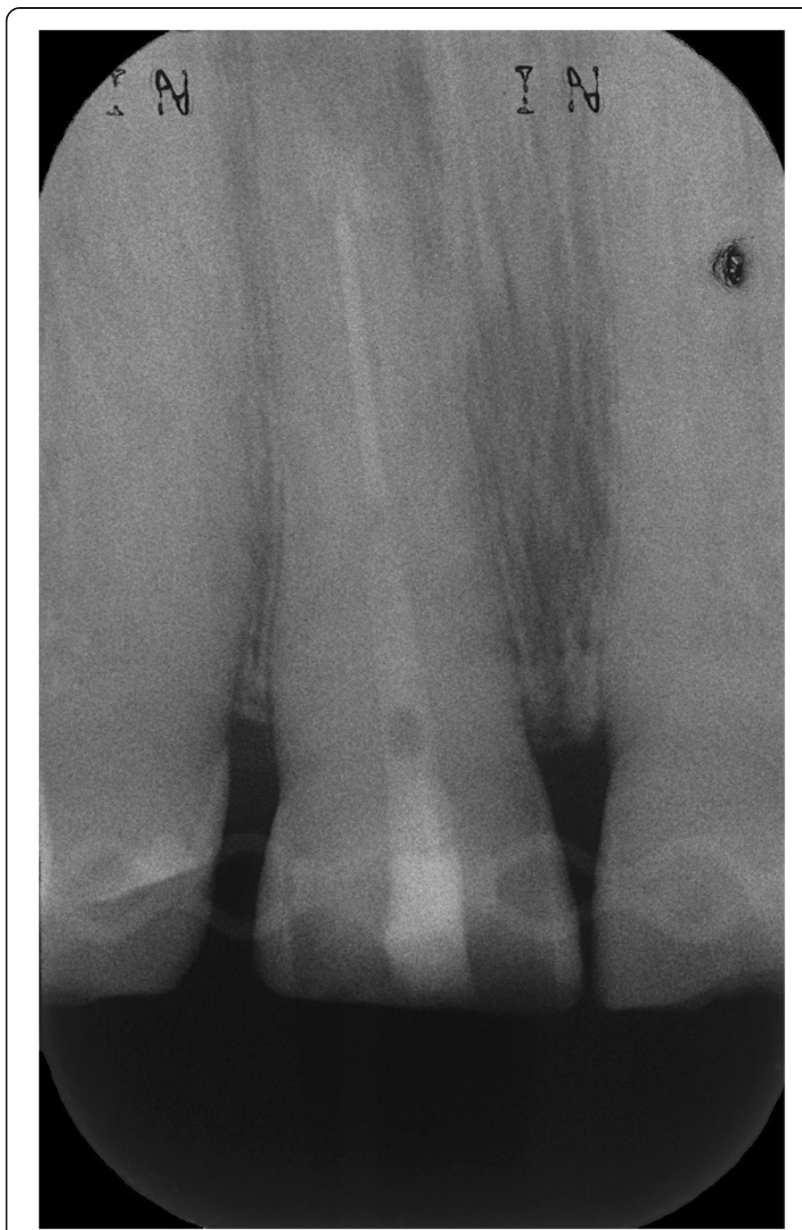

Figure 6 Control radiograph of tooth 11 after replantation.

over the whole period of time. The dental film recorded 24 months after intentional extraction and replantation does not show any pathological findings on tooth 11 (Figure 8).

\section{Discussion}

So far treatment options for VRF are very limited. It is a complication, which leads to extraction in nearly every case [1-5]. Hence, in the present case, extraction of tooth 11 and replacement by implant, bridge or denture was discussed with the patient. But all suggested treatment options after extraction were neither affordable for the patient (implant), nor favoured because of aesthetic properties (bridge) or restricted wearing comfort (denture). Thus, an alternative treatment planning to restore the VRF was required and the use a calcium silicate cement was suggested.

Since its introduction as endodontic reparation cement ProRoot MTA (Dentsply Tulsa, Tulsa, USA) has been examined in several studies; it is meanwhile well accepted and probably the most established material for the treatment of e.g. root-end fillings, apexification or 


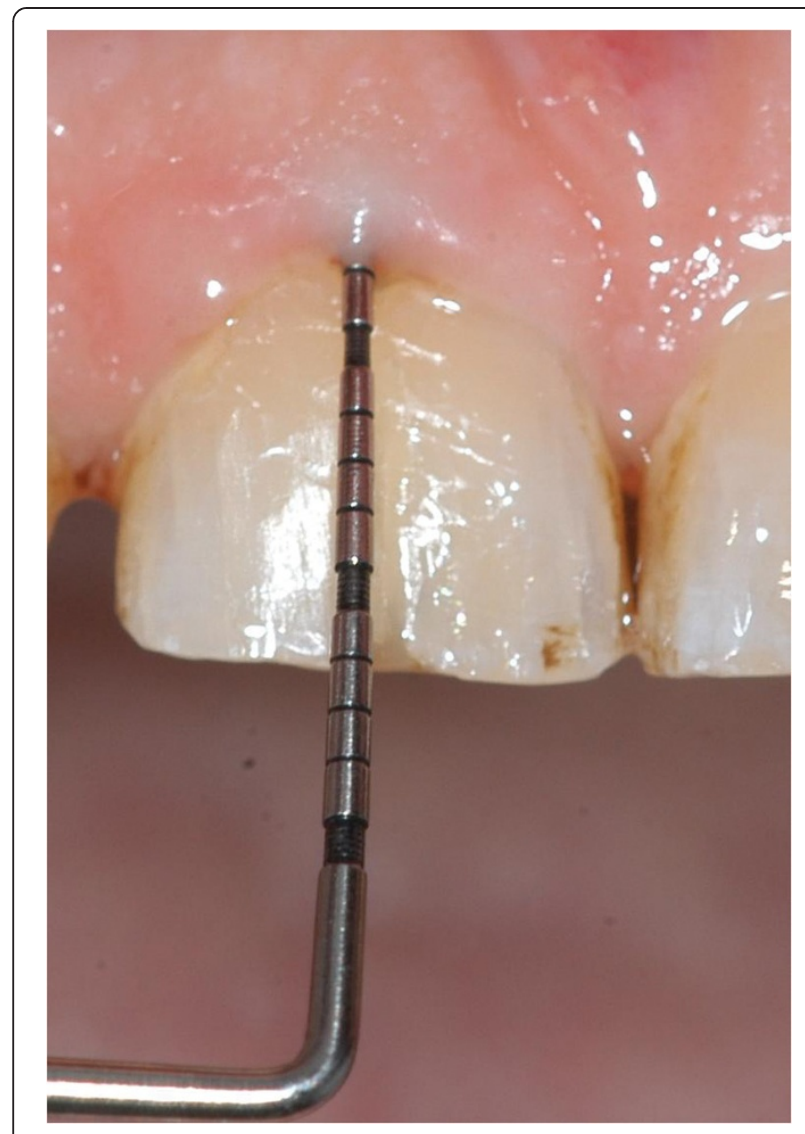

Figure 7 Periodontal probing depth of $3 \mathrm{~mm}$ in the area of the VRF 3 months after operation.

closure of radicular perforations and other dentine defects in the root [22-24]. Hence, the attempt to repair VRF with MTA has been described previously [4,17-19]. Even though ProRoot MTA has many positive features, it also has several drawbacks: difficult handling, long setting time, possible discoloration if used in the visible crown area, lower compressive and flexural strength than dentine (should not be used as a restorative base) and its high costs [25-28]. Thus, over the last years, several calcium silicate cements comparable to MTA have been presented, which can be used as endodontic repair material. One of these materials is Biodentine. It is a bioactive cement mainly consisting of tri- and dicalcium-silicate. When using Biodentine in the repair of VRF it may have some advantages compared to MTA. At first the initial setting time is about 15 min $[28,29]$. Even though Grech et al. evaluated the definite setting time of Biodentine to be $45 \mathrm{~min}$ (according to ISO 9917-1:2007) [30], this is much faster than the mean setting time for ProRoot MTA with $165 \pm 5$ min [31]. Fast setting time is important for the suggested treatment option to keep the extraoral time short to avoid drying of the PDL cells and to provide a resistant filling when replanting the tooth.

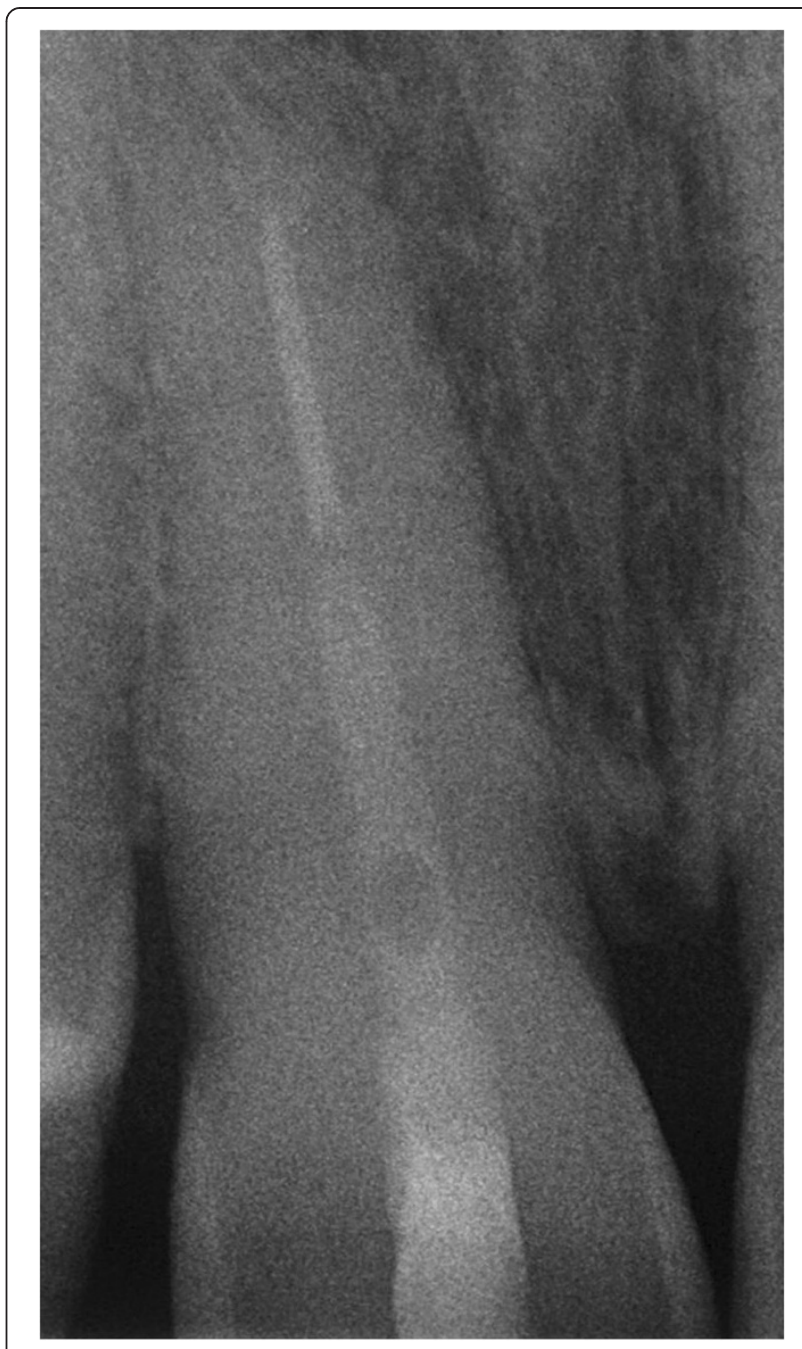

Figure 8 Control radiograph of tooth 1124 months after replantation.

Another positive feature of Biodentine is that its Vickers micro hardness (HV) is approximately $60 \mathrm{HV}$ [32] which is similar to dentine. The HV value of sound human dentine was reported to be between $60 \mathrm{HV}$ and $90 \mathrm{HV}[33,34]$ while the HV for ProRoot MTA was determined to be about $40 \mathrm{HV}$ [35].

According to the manufacturer's information an important advantage of Biodentine is its resistance to hydrolysis while setting. Thus, it could be used as a temporary filling material because it doesn't dissolve in contact with saliva $[28,29,36]$.

Further advantage is its biocompatibility. Biodentine showed significantly higher levels of calcium and silicon ion release than MTA $[37,38]$. Especially silicon plays an important role in the bioactivity of Biodentine. It increases bone calcification $[39,40]$ and stimulates bone growth [41-43]. It also has a positive effect on the mineralization of dentine [44]. 
Furthermore, Biodentine is - identically to MTA - able to develop a hydroxyl apatite-like surface in the presence of body liquids containing calcium or phosphate [45]. This surface is biocompatible and displays good conditions for cell attachment and proliferation of the PDL $[37,45]$. In how far Biodentine had a positive influence on the regeneration of PDL cells cementogenesis and other reparative procedures after intentional extraction followed by replantation can not be evaluated from this clinical case report but need to be studied in further research.

In the present case the tooth 11 was intentionally extracted and replanted, after repair of the VRF with Biodentine. An alternative to the extraction would have been the repair of the VRF by surgical exploration, which has been described in the literature as a possible treatment before $[4,8,17-19]$. This treatment includes dissecting a flap to visualize the bone loss and providing the fracture line with different materials [4,8,17-19].

A disadvantage is that this procedure causes a scar in the visual area of the gingiva. For exploring the extent of the fracture line and its treatment additional osteotomy is necessary which generates extra loss of healthy bone structure. A gingival recession can be expected, so in some regions this procedure is not indicated because of aesthetic considerations [46,47].

Intentional extraction and replantation of a tooth in order to manage VRF has already been described in literature [7,9-16]. Contraindications are teeth, which probably cannot be extracted and repositioned due to a complicated root anatomy, teeth with a severe periodontitis, teeth without adjacent teeth, a non-compliant patient and patients with critical general medical conditions. Before extraction pretreatment of the tooth is necessary. Amalgam or temporary non-adhesive fillings should be removed. Root canal treatment needs to be done prior to the extraction in order to reduce the extraoral time. Approximately two third of the root canal filling should be removed to stabilize the tooth within the root and crown by applying a composite restoration.

In order to preserve the PDL cells an infiltration anaesthesia was preferred over an intraligamentary anaesthesia. The extraction itself should be done as conservative as possible. After loosening the gingiva and the PDL cells at the crestal level with a periotome or a micro-scalpel, the tooth can be slightly loosened out of its socket with a lever. The dental cement and periodontium should be protected as good as possible. When using a forceps, the branches should not exceed the cement-enamel junction. Defects on the cement layer could lead to resorptions or ankylosis [46]. All defect preparation and removing of the retrograde filling should be done under constant cooling with isotonic saline solution.
A short extraoral time of the tooth seems to be very important regarding a positive healing tendency. Drying for an extensively long time would lead the PDL cells to die off, what significantly raises the possibility of root resorptions $[48,49]$. The extraoral time of the tooth after extraction was less than 25 minutes. Within the procedures the root surface was repetitively rewetted with Dentosafe solution.

After treatment of the fracture line with Biodentine and removing the blood clot from the socket with saline rinse, the tooth should be repositioned pressureless and fixed with a titanium trauma splint for approximately 10 days [46]. Longer splinting could lead to ankylosis or resorption $[46,50,51]$.

A systemic administration of antibiotics is not necessary. Even though experimental studies have shown, that its use can decrease the possibility of root resorptions, a clinical report with 400 replanted teeth could not support this effect [52]. Since the extraction and replantation was conducted under ideal clinical conditions, the topical use of antibiotics or dexamethasone as suggested for avulsed teeth after traumatic injuries [48] can also be abstained. The bacterial contamination of the root surface under clinical conditions can be considered to be much lower than after avulsion as a result of an accident. In order to minimize the bacterial content in the oral cavity prior to treatment, the patient should be instructed to use $0.1 \%$ to $0.2 \%$ chlorhexidine oral rinse twice a day, one day before the procedure as well as right before and afterwards. Furthermore, an ideal oral hygiene is mandatory.

\section{Conclusion}

It must be kept in mind that this is a single case study and the observation period of two years is quite short. Thus, it is difficult to extrapolate a single case to a more general conclusion. For a general recommendation, whether this is a suitable treatment option for VRF, more cases over a longer period of time need to be monitored. Nevertheless, intentional extraction and filling the fracture gap with Biodentine followed by replantation is a new clinical treatment option for teeth which have to be extracted elsewise. Hence, the described treatment may contribute to change the clinical practice of VRF in future.

\section{Consent}

Written informed consent was obtained from the patient for publication of this Case report and any accompanying images. A copy of the written consent is available for review by the Editor-in Chief of this journal.

\section{Competing interests}

The authors declare that they have no competing interests. 


\section{Authors' contributions}

Both authors have contributed significantly to this work and contributed to the paper in the equal parts: $\mathrm{PHH}$ had the idea for the treatment and developed the concept, participated in literature research and writing of the manuscript. TD participated in literature research and writing of the manuscript and carried out proofreading. Both authors read and approved the final manuscript

\section{Acknowledgement}

We acknowledge support by Deutsche Forschungsgemeinschaft and Open Access Publication Fund of University of Muenster, Germany.

Received: 20 January 2014 Accepted: 18 March 2014

Published: 26 March 2014

\section{References}

1. Malhotra N, Kundabala M, Acharaya S: A review of root fractures: diagnosis, treatment and prognosis. Dent Update 2011, 38:615-628.

2. Haueisen $H$, Heidemann D: Vertical root fracture: prevalence, etiology, and diagnosis. Quintessence Int 2013, 44:467-474.

3. Berman LH, Hartwell GR: Diagnosis. In Pathways of the Pulp. 9th edition. Edited by Choen S, Hargraves KM. St. Louis: Mosby Elsevier; 2006:23-34.

4. Bargholz C: Vertical tooth and root fractures. In Problems in Endodontics: Etiology, Diagnosis, and Treatment. Edited by Hülsmann M, Schäfer E. London: Quintessence; 2009:353-370.

5. Castellucci A: Endodontic-periodontal interrelationship. In Endodontics. Volume 3. Edited by Castellucci A. Florence: Edizioni Odontoiatriche II Tridente; 2009:756-829

6. Liapatas S, Nakou M, Rontogianni D: Inflammatory infiltrate of chronic periradicular lesions: an immunohistochemical study. Int Endod J 2003, 36:464-471.

7. Oliet S: Treating vertical root fractures. J Endod 1984, 10:391-396.

8. Selden HS: Repair of incomplete vertical root fractures in endodontically treated teeth-in vivo trials. J Endod 1996, 22:426-429.

9. Sugaya $T$, Kawanami M, Noguchi $H$, Kato $H$, Masaka N: Periodontal healing after bonding treatment of vertical root fracture. Dent Traumatol 2001 17:174-179

10. Hayashi M, Kinomoto Y, Miura M, Sato I, Takeshige F, Ebisu S: Short-term evaluation of intentional replantation of vertically fractured roots reconstructed with dentin-bonded resin. J Endod 2002, 28:120-124.

11. Kawai K, Masaka N: Vertical root fracture treated by bonding fragments and rotational replantation. Dent Traumatol 2002, 18:42-45.

12. Kudou Y, Kubota M: Replantation with intentional rotation of a complete vertically fractured root using adhesive resin cement. Dent Traumatol 2003, 19:115-117.

13. Hayashi M, Kinomoto $Y$, Takeshige F, Ebisu S: Prognosis of intentional replantation of vertically fractured roots reconstructed with dentinbonded resin. J Endod 2004, 30:145-148.

14. Oztürk M, Unal GC: A successful treatment of vertical root fracture: a case report and 4-year follow-up. Dent Traumatol 2008, 24:e56-e60.

15. Unver S, Onay EO, Ungor M: Intentional re-plantation of a vertically fractured tooth repaired with an adhesive resin. Int Endod J 2011, 44:1069-1078.

16. Moradi MN, Akhtari $\mathrm{F}$, Araghi $\mathrm{S}$, Homayouni $\mathrm{H}$ : Treatment of a vertical root fracture using dual-curing resin cement: a case report. Case Rep Dent 2012:985215

17. Torabinejad M, Chivian N: Clinical application of mineral trioxide aggregate. J Endod 1999, 25:197-205

18. Taschieri S, Tamse A, Del Fabbro M, Rosano G, Tsesis I: A new surgical technique for preservation of endodontically treated teeth with coronally located vertical root fractures: a prospective case series. Oral Surg Oral Med Oral Pathol Oral Radiol Endod 2010, 110:e45-e52.

19. Taschieri S, Bortolin M, Weinstein T, Del Fabbro M: Preservation of an injured vital tooth using ultrasonic device and mineral trioxide aggregate. Minerva Stomatol 2011, 60:467-477.

20. Castellucci A: Definition, scope and indications for endodontic therapy In Endodontics. Volume 1. Edited by Castellucci A. Florence: Edizioni Odontoiatriche II Tridente; 2004:24-43.

21. Tronstad L: Endodontic complications. In Clinical Endodontics. 3rd edition. Edited by Tronstad L. Stuttgart: Thieme; 2009:215-229.
22. Parirokh M, Torabinejad M: Mineral trioxide aggregate: a comprehensive literature review-part I: chemical, physical, and antibacterial properties. J Endod 2010, 36:16-27.

23. Torabinejad M, Parirokh M: Mineral trioxide aggregate: a comprehensive literature review-part II: leakage and biocompatibility investigations J Endod 2010, 36:190-202.

24. Parirokh M, Torabinejad M: Mineral trioxide aggregate: a comprehensive literature review-part III: clinical applications, drawbacks, and mechanism of action. J Endod 2010, 36:400-413.

25. Karabucak B, Li D, Lim J, labal M: Vital pulp therapy with mineral trioxide aggregate. Dent Traumatol 2005, 21:240-243.

26. Stropko J: Micro-surgical endodontics. In Endodontics. Volume 3. Edited by Castellucci A. Florence: Edizioni Odontoiatriche II Tridente; 2009:1118-1125.

27. Belobrov I, Parashos P: Treatment of tooth discoloration after the use of white mineral trioxide aggregate. J Endod 2011, 37:1017-1020.

28. Dammaschke T: Direct pulp capping. Dentist 2011, 27(8):88-94.

29. Laurent $\mathrm{P}$, Camps J, De Meo M, Dejou J, About I: Induction of specific cell responses to $\mathrm{a} \mathrm{Ca}_{3} \mathrm{SiO}_{5}$-based posterior restorative material. Dent Mater 2008, 24:1486-1494.

30. Grech L, Mallia B, Camilleri J: Characterization of set intermediate restorative material, biodentine, bioaggregate and a prototype calcium silicate cement for use as root-end filling materials. Int Endod J 2013 46:632-641.

31. Torabinejad M, Hong CU, McDonald F, Pitt Ford TR: Physical and chemical properties of a new root-end filling material. J Endod 1995, 21:349-353.

32. Pradelle-Plasse N, Tran X-V, Colon P: Physico-chemical properties. In Biocompatibility or Cytotoxic Effects of Dental Composites. Edited by Goldberg M. Oxford: Coxmoor; 2009:184-194.

33. Fuentes V, Toledano M, Osorio R, Carvalho RM: Microhardness of superficial and deep sound human dentin. J Biomed Mater Res A 2003, 66:850-853

34. Lai YL, Yang ML, Lee SY: Microhardness and color changes of human dentin with repeated intracoronal bleaching. Oper Dent 2003, 28:786-792.

35. Danesh G, Dammaschke T, Gerth HU, Zandbiglari T, Schäfer E: A comparative study of selected properties of ProRoot mineral trioxide aggregate and two Portland cements. Int Endod J 2006, 39:213-219.

36. Koubi G, Colon P, Franquin J-C, Hartmann A, Richard G, Faure M-O, Lambert $\mathrm{G}$ : Clinical evaluation of the performance and safety of a new dentine substitute, biodentine, in the restoration of posterior teeth - a prospective study. Clin Oral Investig 2013, 17:243-249.

37. Han L, Okiji T: Uptake of calcium and silicon released from calcium silicate-based endodontic materials into root canal dentine. Int Endod J 2011, 44:1081-1087.

38. Han L, Okiji T: Bioactivity evaluation of three calcium silicate-based endodontic materials. Int Endod J 2013, 46:808-814.

39. Carlisle EM: Silicon: a possible factor in bone calcification. Science 1970 167:279-280.

40. Carlisle EM: Silicon as a trace nutrient. Sci Total Environ 1988, 73:95-106.

41. Patel N, Best SM, Bonfield W, Gibson IR, Hing KA, Damien E, Revell PA: A comparative study on the in vivo behavior of hydroxyapatite and silicon substituted hydroxyapatite granules. J Mater Sci Mater Med 2002, 13:1199-1206.

42. Porter $A E$, Best $S M$, Bonfield W: Ultrastructural comparison of hydroxyapatite and silicon-substituted hydroxyapatite for biomedical applications. J Biomed Mater Res A 2004, 68:133-141.

43. Porter $A E$, Bothelo CM, Lopes MA, Santos JD, Best SM, Bonfield W: Ultrastructural comparison of dissolution and apatite precipitation on hydroxyapatite and silicon-substituted hydroxyapatite in vitro and in vivo. J Biomed Mater Res A 2004, 69:670-679.

44. Saito T, Toyooka H, Ito $S$, Crenshaw MA: In vitro study of remineralization of dentin: effects of ions on mineral induction by decalcified dentin matrix. Caries Res 2003, 37:445-449.

45. Gandolfi MG, van Lunduyt K, Taddei P, Modena E, van Meerbeek B, Prati C: Environmental scanning electron microscopy connected with energy dispersive X-ray analysis and Raman techniques to study ProRoot mineral trioxide aggregate and calcium silicate cements in wet conditions and in real time. J Endod 2010, 36:851-857.

46. Andreasen JO, Andreasen FM, Andersson L: Textbook and Color Atlas of Traumatic Injuries to the Teeth. 4th edition. London: Wiley-Blackwell Publishing; 2007.

47. Olsburgh S, Jacoby T, Krejci I: Crown fractures in the permanent dentition: pulpal and restorative consideration. Dent Traumatol 2002, 18:103-115. 
48. Andersson L, Andreasen JO, Day P, Heithersay G, Trope M, DiAngelis AJ, Kenny DJ, Sigurdsson A, Bourguignon C, Flores MT, Hicks ML, Lenzi AR, Malmgren B, Moule AJ, Tsukiboshi M: International Association of Dental Traumatology guidelines for the management of traumatic dental injuries: 2. Avulsion of permanent teeth. Dent Traumatol 2012, 28:88-96.

49. Andreasen JO, Hjorting-Hansen E: Replantation of teeth. II. Histological study of 22 replanted anterior teeth in humans. Acta Odontol Scand 1966, 24:287-306.

50. Andreasen $\mathrm{J}$ : The effect of splinting upon periodontal healing after replantation of permanent incissors in monkeys. Acta Odontol Scand 2013, 33:313-323.

51. Andersson L, Lindskog $S$, Blomlof L, Hedstrom KG, Hammarstrom L: Effect of masticatory stimulation on dentoalveolar ankylosis after experimental tooth replantation. Endod Dent Traumatol 1985, 1:13-16.

52. Andreasen JO, Jensen SS, Sae-Lim V: The role of antibiotics in preventing healing complications after traumatic dental injuries: a literature review. Endod Topics 2006, 14:80-92.

doi:10.1186/1746-160X-10-9

Cite this article as: Hadrossek and Dammaschke: New treatment option for an incomplete vertical root fracture-a preliminary case report. Head \& Face Medicine 2014 10:9.

\section{Submit your next manuscript to BioMed Central and take full advantage of:}

- Convenient online submission

- Thorough peer review

- No space constraints or color figure charges

- Immediate publication on acceptance

- Inclusion in PubMed, CAS, Scopus and Google Scholar

- Research which is freely available for redistribution 